\title{
NEPAL'S ATTEMPT TO ESCAPE ASYMMETRICAL INTERDEPENDENCE WITH INDIA
}

\author{
Gaurav Raj Dahal
}

\begin{abstract}
Nepal and India share interdependence with each other regarding economy and politics. India, as a powerful nation with adequate structural power, has been seen meddling with Nepal's internal affairs and exploiting its economic and political vulnerability. The overall objective of this paper is to analyze the Nepalese foreign policies towards India and its attempt to escape this asymmetrical interdependence throughout the history till date. This paper also tries to identify the factors that influence the formulation of Nepalese foreign policies as well as the consequences of the implemented policies. Additionally, the study shows that with the ongoing radical changes brought by series of democratic successes in Nepalese political system, the traditional approach of Nepalese political leaders that existed before can be changed. Nepal is at a critical juncture where the policies it will make can change significantly with the assistance of international and regional regimes.
\end{abstract}

Keywords: Nepalese foreign policy, complex interdependence, independent, asymmetry

\section{Background}

Nepal is situated in the South Asian region of the globe. It is a landlocked country with a total area of 147,181 square kilometers and is surrounded by the two major countries in Asia, China and India. Nepal is separated from China in the north by series of mountain ranges consisting of some of the tallest mountains on the planet. In the south, west and east, Nepal has border with 
India. For these reasons, many view Nepal as "India-landlocked" rather than just landlocked (Ojha, 2015). Nepal has several allweather trading routes with India, which have been used by both the countries extensively since the past. The two countries also share 'free border' under which people from one country can travel to another country without visa requirements under the treaty of 1950. This has become possible because Nepalese people have cultural, linguistic and ethnic similarities with those of Indians. Such similarities are also a primary reason for close people-to-people ties of Nepal with India since ancient times (Dahal, 2011). More importantly, these similarities and close ties have shaped mutual dependence among these two nations.

\section{Objective of the Study}

The purpose of this research is to understand and analyze the foreign policies adopted by the Nepalese government towards India, specially focusing on the patterns as well as the intentions and goals of these policies. This paper also aims to understand the outcomes and consequences of these policies implemented, conditional on various periods of time and, domestic and regional scenarios under which they were formulated. As will be discussed in following Chapters, Nepalese foreign policy will be thoroughly analyzed using complex interdependence approach examining the policies implemented till date. Additionally, this study attempts to understand the contemporary FPs being implemented by Nepal towards India and how they are being affected by current political instability and Nepal's increasing engagement with International regimes.

\section{Conceptual Framework}

According to Keohane and Nye's Power and Interdependence, power is the ability of any actor to change the pattern of behavior 
of another actor according to their will. In political analysis of international system every country has their own resources and capabilities to change policy alternatives. To better understand the sources of power among any countries we can compare and analyze asymmetrical interdependencies among them, i.e. how vulnerable or how sensitive their policies are to each other.

No country in this world is self-sufficient enough to be able to survive by itself. Therefore, countries interact with each other in several ways to fulfill their needs. In this process, they involve themselves in mutual relationships where both the countries share mutual benefits from the transactions, be it social, political or economic (Baldwin, 1980). Consequently, the countries become dependent upon each other to fulfill their demands.

Baldwin in his article Interdependence and power, states that the current state of globalization, with improvements in communications, has enhanced international interdependences where countries interact and perform transactions with each other. He also argues that the countries live in peace and economic well-being as mutual benefits from this interdependence. Therefore, to sustain such relationships, normative measures like disarmaments or international regimes should be formed or else the countries will not be able to share this benefit from international interdependence (Baldwin, 1980).

Interdependence can be understood as the relationship between two countries wherein it would be mutually costly if the relationship comes to an end. According to Kroll, a country is vulnerable, if and when the relationship between two states is in position to be broken, the cost of such change is difficult for the country to bear. If the cost of this change is equal for both the countries then these countries share mutual vulnerability, which can also be termed as interdependence between these two 
countries. Similarly, the country is said to be dependent on other if the cost of this change in relationship is higher in comparison to the cost of the latter. This is the situation where these countries share asymmetrical interdependence, where one suffers less than the other. Keohane and Nye suggest that this asymmetrical relationship becomes sources of power for the countries that are less dependent, as their bargaining power increases in the issuesareas where they interact with one another and is able to exploit and influence it.

Interdependence consists of two major dimensions: sensitivity and vulnerability. "Sensitivity involves degrees of responsiveness within a policy framework" (Keohane \& Nye, 1937. 2001). It means that sensitivity interdependence is the process of interactions between countries where no alternative polices are available with which a country can cope up with the change in relationship with another country. It is the measurement of cost involved in the change of one country's policy in response to the change in another's. Here, Sensitivity reflects the liability to the costs that has to be suffered by the country within a framework of policies. Vulnerability, on the other hand, is the ability of the state to suffer the cost imposed by another country using various alternative policies available.

If the state is able to choose a best policy from various alternatives of policies, then the study of vulnerability interdependence provides significant understanding of the relationship between interdependence and the power of the country. Policy makers are supposed to understand the country's actual or potential vulnerability interdependence while forming and implementing policies. They have the responsibilities to protect the interest of the people through implementation of the best policy from various policies available. Therefore, if any country implements 
its policy without giving much consideration to its actual and potential vulnerabilities in order to manipulate unequal sensitivity, interdependence will not be successful. Literature Review

Nepal has never been colonized by any other countries, whereas both of its bigger neighbors have been the victim of colonization in the past (Subedi, 1994). This has been regarded by the Nepalese as the result of bravery of the Nepalese people and the ability to remain independent as a sovereign state without any foreign interferences. This notion is still alive in most of the people till date. Therefore, heavy reliance on the India for its economic activities and developments process has been regarded by the Nepalese people as an interference on Nepalese sovereignty making it dependent and vulnerable. For instance, the blockade imposed by the Indian government during 1988 is considered to be based on the Indian government's motives to use Nepal exploiting the transit issues and economic dependency. This has become the major reason for the development of the "anti-Indian sentiment" among the Nepalese people till date. As a small nation Nepal has considered India to interfere in the Nepalese politics time and again to achieve its geopolitical interest over China. This has been perceived as India being a hegemon by the Nepalese people.

According to Dahal, the political instability of Nepal has poised significant amount of misunderstanding and mistrust with international community. This has been caused by the frequent change in the government leadership, which is then followed by the continuous change of the policies failing to fulfill the national interest and forming cohesive foreign policy. This has also been the major reason for the lack of unity among the political leadership in Nepal as these policies are formed 
solely based on their personal interest and gains. As the writer describes, national interest of any country is temporary and can change overtime, "National interest can also be judged along time dimensions."(Dahal, 2011) The national interest of the country which was survival at one point of time dealing with the capacity to defend itself from the external attacks and pressure ensuring the national security may change over time to vital interest of the state which is responsible for the national building through strengthening of the national identity among the people. This can again change to major interest mainly seeking the cooperation for the optimum utilization of available resources (Dahal, 2011).

Nepal contains the geo-political advantage because it has two economic and technological super power countries as its neighbor with huge population, huge markets and industries. Historically, most of the times, Nepal has been able to maintain its close relationship with its neighbors than they are able to maintain with each other (Dahal, 2011). Situated between these nations, Nepal has the potential to be the hub for trade and commerce by being capable to perform as the transit for these two economically growing countries. In the past, Nepal has been regarded as the nation with Hindu majority where the ruling class has always been the elites from Hindu society. The Indian states of Uttar Pradesh, West Bengal and Bihar bordering with Nepal also consist of the people sharing the same religious and cultural ties with Nepalese people. Due to this reason, the policies and patterns implemented by the Nepalese government were significantly directed towards India. In recent times, as Nepal is galloping towards more secular system providing privileges equally to all its people, achieving democratic successes. The policies that it forms now may differ from the past policies where it uses soft power maintaining relationship 
with India based on these ethnical ties, instead it may search for geo-political advantage it possesses in between these economic super power countries regarding trades, economy, technologies.

Historically, Nepal also has a bitter experience of being defeated and being compelled to sign treaties and agreements where it lost its territories, trading rights and most of all the national integrity just because it was not able to maintain the evenly balanced mutual dependence between its two super power neighbors, with China in 18th century and with British India in 19th century (Dahal, 2011). In 1950, when Sino-Indian war occurred, it became clear that it was necessary for Nepal to maintain the relationship with the powerful China as well. Nepal who was sharing Special relationship with India (Muni, 1973), neutralized its relationship and adopted the non-alignment policy by extending the diplomatic relationship with the US, China, Soviet Union, Japan and other. The major reason for Nepal to pursue this strategy for giving up the special relationship with India was to balance the interdependence between its neighbors and set itself free to pursue its national interest in the International System. With this strategy Nepal aimed to decrease its overall dependency and security challenges with India. This was considered to be the policy of Nepal to get rid of the vulnerable situation and maintain its national security and integrity. Therefore, the development of Nepal, either it be economic prosperity, political development or national security, significantly depends on how it manages the relationship between its two neighbors and represents itself and contributes in the international arena (Dahal, 2011).

After abolition of monarchy and declaration of Nepal as a secular state by the new government after 2006, Nepalese people suffered with the identity crisis increasing more differences regarding their ethnicity, class, religion, etc. (Dahal, 
2011). These differences have been the major reason for Nepal straining to achieve single national interest and achieve political stability because regional and religious identities are gradually becoming national identities. These differences of identities have made the country's political system unstable. Political parties provoking these differences for their survival-oriented strategies has resulted in producing adverse political condition in Nepal which is further worsened by the "intolerable political ideologies, schematic party loyalties, and the emerging issue of ethnic identity" (Bhandari. 2012).

\section{Nepalese Foreign Policy Under the Lens of Complex Interdependence}

In case of the relationship between Nepal and India, it can be seen that Nepal being a developing landlocked country, its relationship with India highly depends upon the foreign policies it plans and implements towards it. The economic interdependence has consistently compelled GoN to form policies to escape the economic and political dependence searching for other possible options, the most prominent one being enhancing the relationship with China in order to minimize the vulnerability interdependence towards India.

Nepal's lack of alternative options for its economic trade and transactions can be viewed as the vulnerability interdependence of Nepal. As a landlocked country, if Nepal can achieve economic support and assistance from any other alternatives, either it be from China or other international regimes that reduces the dependency of Nepalese economy towards India, Nepal's vulnerability can be analyzed to be minimum.

\section{Sino-India Rivalry}

Throughout the history there has always been the presence of 
bilateral competition between India and China. These two rivals have also been in war during 1962, where India was relatively less powerful militarily compared to China. Since then, avoiding direct military confrontation with China has always been the major interest of India. India perceives Nepal as a crucial territory to keep itself distant from the Chinese territory. This has been accomplished in the past as Nepal's relationship, economic and political, was inclined towards India.

Nepal as a sovereign and independent territory kept India from having direct confrontation with China. Therefore, less Chinese influence in Nepal is in the interest of India. It is also because if China increases its influence over Nepal, India's power to influence the south Asian nations will also relatively decrease. India, whenever it sees the relationship between China and Nepal growing, uses economic blockade as a tool to disrupt this building of relationship utilizing the economic dependence of Nepal over India. This imposing of blockade can be seen as an instrument of India to affect Nepal's vulnerability and to distort the relation building process with China. The imposing of blockade can be perceived as India's bargaining tool with Nepal, the way it uses direct military confrontations with its neighbor Pakistan which can be seen time and again.

Moreover, Indian aggression over its neighbor Pakistan during Indo-Pak war of 1971 was perceived by Nepal as India a powerful nation exerting its force on its weaker neighbor. This was huge challenge for Nepal's national security which was even weaker in both economic and military terms than Pakistan. The policy of non-inclination did not seem to function for Nepal's security as it was implemented in order to counterbalance the influence of its neighbor. Maintaining equidistance with both of its neighbor, Nepal's strategy was to secure itself from being the prey of 
aggression of either of its neighbor. The statesman expected that one of its neighbors will assist the nation if the other tries to attack or harm. With the defeat and dismemberment of Chinese ally, Pakistan and the government of Nepal realized that China, as a super power will help Nepal if India tries to attack Nepal. China was helpless during this war to protect its neighbor. With India being the sixth nuclear power country after successfully testing the nuclear bomb 'Smiling Buddha' (MEA designation: Pokhran-I) on May 18, 1974, Nepal was caught between two nuclear power rival neighbors. Nepal who lacked serious military and economic abilities couldn't afford to maintain policy of non-alignment between these two rival superpowers. Therefore, policy of zone of peace was considered to be the best policy option for Nepal.

\section{Hegemony and Hegemon}

Keohane and Nyein in their book Power and Interdependence advocates that in today's world the ability of an individual state to manipulate the asymmetrical interdependencies with other countries are limited by the frameworks of international interdependencies. Here, the theory assumes that if any country gets stronger then the country is likely to dominate other weaker nations. But international interdependencies will prevent these powerful nations from exerting power, as these ministates like Nepal will be able to form groups with other countries with similar conditions and force powerful state to change the policies.

For instance, the first foreign visitor to greet prime minister Oli after becoming the Prime Minister for the second time was the prime minister of Pakistan Shahid Khaqan Abbasi. This visit from Pakistani prime minister was perceived unusual because even though Nepal and Pakistan are both located in the south Asian region and are neighbors with both China and India, they 
do not really share the intimate ties. Historically, Nepalese prime minister would have foreign visitors from India as well as China (Jha, 2018).

Pakistan is also considered as the rival of India. They have engaged in two wars against each other. They do not share good relationship with one another. Therefore, this visit from Pakistani Prime minister can be perceived as small countries allying themselves to counter balance the power of the big country.

Throughout the history, India and China were trying to influence Nepal for their own benefits. Nepal as a landlocked country was majorly dependent on the aid and support provided by these two economically powerful nations. Nepal also lacked military ability even to defend itself from the aggression of these two countries if the situation ever arose. It also lacked the capacity to compete with these two nations either economically. From the historical evidence we can perceive that Nepal lacks the capacity to act independently. This can be seen from its policy of 'nonalignment' and 'special relationship with India' that have been unsuccessful to achieve its goal (Rose and Dial, 1969).

"Good motives give assurance against deliberately bad policies; they do not guarantee the moral goodness and political success of the policies they inspire." (Morgenthau, 1993) The country's political leader may act rationally and implement foreign policies with good intentions but we cannot assume that his policies will surely achieve political success. Therefore, to understand the foreign policies of any country, we should consider the intellectual ability of the statesman to understand the important elements of the foreign policies instead of his motives.

In case of Nepal, during the Shah regime, rational foreign policies were implemented according to the necessity of the national interest. The kings were rational and well equipped with 
the advisors who had proper knowledge about the formation and implementation of the policies to achieve the national interest. From the 1962 Sino-India war, the kingdom understood that to achieve sovereign state, Nepal must have policies that are not inclined to either of its neighbor. China was perceived by Nepal as a powerful country than India with whom it has been maintaining its "special relationship". As Morgenthau has stated that even the rational steps taken by the statesman do not guarantee successful results. This statement holds true in Nepal's case because even though King Mahendra's policy of non-alignment was an attempt to achieve the independence of Nepal, it cannot be considered successful. His goal to reduce the vulnerable situation from the economic dependency with India and to achieve situation where both the countries share mutual benefits was not achieved.

\section{Contemporary Nepalese Foreign Policy}

In this stage of globalization, no country can achieve development in the state of isolation. Countries are now dependent on each other economically, technologically, socially and so on. No country in today's world can imagine surviving without the cooperation with other countries; especially, landlocked countries like Nepal are significantly dependent on its neighbors for economic assistance. Beasley states that an increase in such interdependence may have negative consequences for some countries (Beasley, 2012). One country's economic gain can be another country's economic loss. Similarly, the more dominant partner in this relationship may also try to exploit the weaker partner and influence their decision-making process for their own benefits (Beasley, 2012). 


\section{Oli's Diplomacy}

The major objectives of the Oli government were to maintain foreign policies without external influence and achieve national interest and independence. Therefore, to attain economic prosperity and development, the principles of Panchsheel Agreement (Arpi, 2004), non-alignment, UN Charter and international Law were to be followed to play significant role in global politics and not just remain concerned trying to balance the relationship with India and China like past leaders. In spite of these goals, like every other statesman, K P Oli also became entangled in maintaining the relationship with the neighbor countries (Wagle, 2018).

After becoming the Prime Minister for the first time, K.P Oli announced his first trip abroad to China in early 2016. During this visit, Oli signed transit and transport agreement with China which will provide Nepal access to Chinese Tianjin, Shenzhen, Lianyungang and Zhanjiang open seaports and Lanzhou, Lhasa and Xigatse dry ports for trading with third countries (Mohan, 2018.). The primary purpose of this treaty was to diversify the Nepal's economic and trade engagements with its neighbors, ending Indian government's hegemonic monopoly (Bhattrai, 2018). He also signed Memorandum of Understanding (MoU) for building railways from China to Nepal. As this understanding stated that the railways will be connected to the Lumbini 'the birth place of Buddha', which is also near the border with India, Indian government criticized the agreement between these two countries and stated its dissatisfaction. Then, the plan was dropped and the railways was agreed to touch only till Kathmandu (Bhattrai, 2018). This also can be perceived as India's ability to influence in the events happening inside Nepal, even though they do not directly concern them and pertain to a third country. 
On his second term as a Prime Minister on February 15 2018, Oli made his first foreign visit to India, following the trend of his predecessors. During his first term as the prime minister, Oli blamed India for the then ongoing blockade stating that, "India has imposed an 'unofficial border blockade'. It would not be appropriate for me to visit India unless the situation returns to normal."(Singh, 2017) This visit to India keeping the tradition of making India as a first foreign visit by Oli as a prime minister can also be perceived as his steps to mend the troubled relationship with India during his first term as prime minister. From his speeches and his mission that he expressed during his first term; people have speculated that the Oli government would again try to increase its closeness with the Chinese government. Despite the speculation, Oli's first foreign visit to India and after that Modi's visit to Nepal can be understood as Oli's government policy to amend the fraught relationship with the government of India.

Soon after, Oli also made his visit to China. Oli had been accusing that the prime ministers before him, Sher Bahadur Deuba of NCP and Puspha Kamal Dahal from CPN(M) Party, had not been able to implement the treaties agreed upon between the Chinese government and his government during his first term as the Prime Minister in 2016. Despite such claims, he himself had not been able to implement those treaties effectively even in his second term. The agreements and treaties signed with China during his first term as a prime minister in 2016, which were considered of significant importance, did not get much attention during his second visit. This delay of the implementation of those treaties and agreements can also be perceived as the result of him trying to amend the strained relationship with India during his first term as a prime minister. 
With these visits, we can perceive that Oli is making his policies rationally with India by taking prudent steps to deescalate the tension in the relationship between each other and enhancing the relationship with China as well. Nepalese economic development and prosperity was slowed down because of the two decades of political instability and conflicts. During this time, all the people realized the sensitivity regarding the Indian policy change to Nepal. They realized there was strong need of policies to amend this dependent stature of Nepal towards India. Soon, it also became clear that maintaining the relationship with India is the best possible relationship alternative for Nepal. It is in Nepal's interest that it tries to amend this asymmetric interdependence with India to mutual Interdependence.

\section{Conclusion}

The development of Nepal, either it be economical prosperity, political development or national security, significantly depends upon how it manages the relationship between its two neighbors and represent itself and contributes in the international arena (Singh, 2017). In spite of having multidimensional bonds, the leaders of Nepal have also felt that the dependency over India is increasing making Nepal vulnerable. This has also significant impact on the policies they form and implement. This was also the major reason for these statesmen to seek for counter balance to Indian hegemonic power by enhancing relationship with China. But whenever these statesmen took steps to form a nonaligned or policies with less Indian influence, India has been misusing Nepal's economic dependency over it to induce the leaders to do otherwise. It has been seen imposing economic blockades time and again when ever Nepal tried to foster its relationship with the China.

Like every other nation in this globalized world, Nepal also lacks 
the ability to be self-sufficient, either economically or militarily, without the support of external actors. Therefore, Nepalese policy makers have to admit its vulnerable position and try to transform its dependent economy to relatively self-sufficient economy. In order to achieve these goals, Nepal can seek and leverage on the assistances and aids provided by International organizations like UN, WTO and so on. This process of development will ensure Nepal's sovereignty as well as make Nepal economically developed which will play a significant role in global arena.

We can also see from these analyses that the efforts made to escape the asymmetrical interdependence by Nepal was unsuccessful as Nepal was vulnerably dependent towards India without any other possible options, neither china nor other international institutions. At the moment, Nepal is in a critical juncture. It has been able to achieve series of democratic successes, from abolition of Rana Oligarchy and autocratic monarchy, to peace agreements with Maoist rebels and promulgation of new constitution. These events coincided with the growing presence of international agencies - development partners, multilateral institutions, bilateral institution, INGOs - in Nepal. In fact, these agencies, in many ways, fostered conducive environments through dialogues and other supports for the changes to take place. As such, with this increasing presence of international and regional institutions Nepal can utilize this as a turning point to shift its approach of foreign policies from traditional approach where Nepal can rely for aid and support with these developing partners instead of relying only on India. Nepal can uplift their role further for its developmental purpose as these non-state actors have increasingly been able to assist countries like Nepal for providing required support for proper shaping of social and political developments. With this enhancement of involvement, with these international and regional institutions, Nepal can also 
play a significant role in global politics.

\section{References}

Baral, B. N. (2018). Changing dynamics of Nepalese foreign policy: Patterns and trends. Journal of Political Science, 18, 25-45. Retrieved from https://doi. org/10.3126/jps.v18i0.20437

Beasley, Ryan K., Juliet Kaarbo, Jeffrey S. Lantis, and Michael T. Snarr (2012). Foreign policy in comparative perspective: Domestic and international influences on state behavior. Sage. 10.

Bhandari, Surendra (2012). The king versus the people: The abolition of monarchy and constitution making in Nepal. Available at SSRN 2367755.

Bhattrai, Kamal Dev (2018). Nepal-China: Reality sets in. The Diplomat. Retrieved from https://thediplomat. com/2018/06/nepal-china-reality-sets-in/

Bhattrai, Kamal Dev (2018). The- China -India -Nepal-triangle. Will India agree to cooperate with China in Nepal's development? The Diplomat. Retrieved from https:// thediplomat.com/2018/04/the-china-india-nepaltriangle/

Claude, Arpi (2004). Born in sin: The panchsheel agreement: The sacrifice of Tibet. Mittal Publications.

David A. Baldwin (1980). Interdependence and power: A conceptual analysis. International Organization 34(4), 471-506.

Dahal, Dev Raj (2011). The Art of Survival: Policy Choices for Nepal. Vol. 5. Dhaulagiri Journal of Sociology and Anthropology. 
Dahal, Girdhari (2018). Foreign relation of Nepal with china and India. Journal of Political Science, 18, 46-61.

Geeta Mohan (2018). Nepal-China transit agreement ends sole dependence on India. India Today.

Government of Nepal Ministry of Foreign Affairs MOFA. Retrieved from: http:// mofa.gov.np/foreign-policy/ foreign-policy/

Institute of foreign Affairs (IFA) (2012). A Report on Emerging Challenges of Nepal's Foreign Policy. Institute of Foreign Affairs and Friedrich Ebert Stiftung. Dillibazar, Kathmandu.

Jha, Prashant (2018). Is it the end of India's special relationship with Nepal? Hindustan times.Retrieved from https:// www.hindustantimes.com/india-news/is-it-the-endof-india-s-special-relationship-with-nepal/storyijLN15AvvOt1w6fQANekVP.html

Ju, Chang Bum, and Shui-Yan Tang (2011). Path dependence, critical junctures, and political contestation: The developmental trajectories of environmental NGOs in South Korea. Nonprofit and Voluntary Sector Quarterly, 40(6), 1048-1072.

The Kathmandu Post (2018). Pakistan PM to arrive on March 5 for 2-day state visit. Retrieved from http://kathmandupost. ekantipur.com/news/2018-03-02/pakistan-pm-to-arriveon-march-5-for-2-day-state-visit.html

Keohane, Robert O. (1941), and Nye, Joseph S., Jr., (1937, 2001). Power and Interdependence. $3^{\text {rd }}$ ed. New York; Tokyo: Longman.

Mishra, Ipsita (2018). Is Nepal-India 'special relationship' undergoing a fundamental shift? The Initiative for Policy 
Research and Analysis. Retrieved from http:/inpra. in/2018/04/13/is-the-nepal-india-special-relationshipundergoing-a-fundamental-shift/

Morgenthau, Hans Joachim, 1904-1980, Kenneth W. Thompson 1921, and W. David Clinton. (2006). Politics among nations: The struggle for power and peace. $7^{\text {th }}$ ed. Boston: McGraw-Hill Higher Education.

Muni, S.D. (1973). Nepalese Foreign Policy. India; NATIONAL PUBLISHING HOUSE 23, Darya Ganj, Delhi.

Nayak, Nihar R. (2016) Landlocked and Transit Developing Countries: Nepal's Transit Route Negotiations with India Strategic Analysis, 40(2).

Neelakantan, Anagha (2015). Nepal's Political Faultlines. International Crisis Group. Retrieved from: https:// www.crisisgroup.org/asia/south-asia/nepal/nepal-sconstitution-ii-expanding-political-matrix

Ojha, Hemant (2015). The India-Nepal crisis. The Diplomat. https:/thediplomat.com/2015/11/the-india-nepal-crisis/

Pant, Bhuwaneswor (2018). Socio economic impact of undeclared blockade of India on Nepal. Research Nepal Journal of Development Studies 1(1).

Raymond, Gregory A. (1998). Necessity in foreign policy. Political Science Quarterly 113(4), 673-88.

Rose, Leo E., and Roger Dial (1969). Can a ministate find true happiness in a world dominated by protagonist powers? The Nepal cases. The Annals of the American Academy of Political and Social Science 386(1).

Shrestha, Subina (2017). Is Nepal headed towards the communist state? Al Jazeera News. Retrieved from https://www. aljazeera.com/blogs/asia/2017/10/nepal-headed- 83 - Journal of Political Science, Volume XIX 
communist-state-171014095129113.html

Singh, Binodkumar (2017). Nepal-India ties in 2016: Relationship that remained troubled. Analysis. Eurasia Review. Retrieved from https://www.eurasiareview. com/15012017-india-nepal-ties-in-2016-a-relationshipthat-remained-troubled-analysis/

Subedi, Surya P. (1994). India-Nepal security relations and the 1950 treaty: Time for new perspectives. Asian Survey 34(3).

Wagle, Geja Sharma (2018). Oli's Foreign Policy. The Kathmandu Post. Retrieved fromhttp://kathmandupost. ekantipur.com/news/2018-06-15/olis-foreign-policy. html 